\title{
Mixtures of Low Molecular Weight Surfactant Proteins and Dipalmitoyl Phosphatidylcholine Duplicate Effects of Pulmonary Surfactant in Vitro and in Vivo
}

\author{
GERALD B. SMITH, H. WILLIAM TAEUSCH, DAVID S. PHELPS, AND KEVIN M. W. KEOUGH \\ Department of Pediatrics, Harvard Medical School, Boston, Massachusetts [G.B.S., D.S.P.]; Department of \\ Pediatrics, Drew University of Medicine and Science, Los Angeles, California [H.W.T.]; and Department of \\ Biochemistry, Memorial University of Newfoundland, St. John's, Newfoundland, Canada [K.M.W.K.]
}

\begin{abstract}
Pulmonary surfactant proteins SP-B and SP$C$ were isolated from lavage fluids of bovine lungs and recombined (lipid/proteins, 9/1, wt/wt) with dipalmitoyl phosphatidylcholine for testing in vitro and in surfactantdeficient adult rats. Using a pulsating bubble surfactometer, we found that inflation pressures of bubbles at minimum radii in these mixtures were $0.34 \pm 0.05 \mathrm{~cm} \mathrm{H}_{2} \mathrm{O}( \pm$ $\mathrm{SD}, n=24$ ) after $1 \mathrm{~min}$. These values were not affected by increasing amounts of surfactant protein relative to dipalmitoyl phosphatidylcholine (DPPC). Minimum inflation pressures were similar to those of modified bovine surfactant, surfactant Tokyo Akita (TA) $(0.33 \pm 0.05 \mathrm{~cm}$ $\left.\mathrm{H}_{2} \mathrm{O}, n=7\right)$. In vivo testing was carried out in adult rats made surfactant deficient by repeated lavage and ventilated with $100 \%$ oxygen. Rats received tracheal instillations of either air, DPPC, DPPC/SP-B,C (9:1), or surfactant TA at $50 \mathrm{mg} / \mathrm{kg}$ body weight. Surfactant TA and DPPC/SP$\mathrm{B}, \mathrm{SP}-\mathrm{C}$ mixtures resulted in similar immediate and sustained improvements in arterial oxygenation (308 \pm 66 torr, $n=10$ and $312 \pm 101$ torr, $n=6$ at $30 \mathrm{~min}$ posttreatment) that were significantly greater than those of sham (76 \pm 24 torr, $n=17)$ and DPPC-treated rats $(64$ \pm 32 torr, $n=7$ ). Rats treated with either DPPC/SP-B,C mixtures or surfactant $T A$ showed similar postmortem static lung compliances $\left(2.3 \pm 0.8 \mathrm{ml} / \mathrm{cm} \mathrm{H} \mathrm{H}_{2} \mathrm{O} / \mathrm{kg}, n=8\right.$ and $1.9 \pm 0.4 \mathrm{ml} / \mathrm{cm} \mathrm{H} \mathrm{H}_{2} \mathrm{O} / \mathrm{kg}, n=5$, respectively) that were significantly larger than sham $\left(1.3 \pm 0.3 \mathrm{ml} / \mathrm{cm} \mathrm{H}_{2} \mathrm{O}\right.$ / $\mathrm{kg}, n=14)$ and DPPC-treated rats $\left(1.2 \pm 0.2 \mathrm{ml} / \mathrm{cm} \mathrm{H}_{2} \mathrm{O} /\right.$ $\mathrm{kg}, n=6$ ). We conclude that simple mixtures of DPPC and SP-B,C duplicate results found with more complex mixtures of pulmonary surfactants. (Pediatr Res 23: 484490, 1988)
\end{abstract}

\section{Abbreviations}

SP-A, relatively hydrophilic 30-35 kDa surfactant protein. SP-B,C, hydrophobic surfactant proteins with $\mathrm{m}$.w. ranging between 5,000 to 26,000 Da.

DPPC, dipalmitoyl phosphatidylcholine.

TA surfactant, Tokyo Akita surfactant, Tokyo Tanabe Company, Tokyo, Japan.

Received October 6, 1987; accepted January 7, 1988.

Reprint requests H. William Taeusch, M.D., Director, Division of Neonatology, King/Drew Medical Center, 12021 S. Wilmington Avenue, Los Angeles, CA. 90059.

Supported in part by Grant HL-34616 from the National Heart, Lung and Blood Institute and Ross Laboratories.
SDS-PAGE, sodium dodecylsulfate-polyacrylamide gel electrophoresis

Many recent reports emphasized the functional importance, both in vitro and in vivo, of several pulmonary surfactant proteins with molecular weights that range between 5-26 kDa (1-11). These proteins are markedly hydrophobic $(1,5,7-9,13-23)$, coisolate with lipids in commonly used organic solvents $(1,4-8$, $11,13,15-17,20)$ and may represent monomeric and oligomeric forms of two distinct peptides-SP-B and SP-C $(12,16)$-that are derived through proteolytic processing of larger precursor proteins $(1,21-24)$. Various reports indicate that SP-B and SP$\mathrm{C}$, together or separately, augment phospholipid recycling in cell cultures $(13,14,19)$, enhance absorption $(1,5-8,10)$, surface spreading and dynamic respreading $(6,7,9,10)$, and surface tension-lowering properties of synthetic phospholipid mixtures or protein-free lipid extracts of natural surfactant in vitro (3-11). SP-B and SP-C have also been reported to enhance the abilities of defined lipid mixtures to improve pulmonary compliance in the lungs of premature rabbits $(2,4,6,7,9)$. Many of these studies have only been published recently in preliminary form, and its remains unclear whether good separation techniques are readily available for separation of these two surfactant proteins, one from the other.

We have extended these studies by isolating SP-B,C from bovine lung lavage, combining these proteolipids with DPPC and testing the efficacy of these mixtures in vitro and in surfactant-deficient adult rats. Comparisons were made with DPPC alone and with a modified bovine surfactant used clinically for treatment of respiratory distress syndrome (surfactant TA, Tokyo Tanabe, Co., Tokyo).

\section{MATERIALS AND METHODS}

Isolation of proteins. SP-B,C were isolated from broncheoalveolar lavage of excised lungs from freshly sacrificed calves. Each lung was lavaged four to six times with approximately 0.3 liters of $0.15 \mathrm{M} \mathrm{NaCl}\left(4^{\circ} \mathrm{C}\right)$ that was poured intratracheally and removed by gravity flow with gentle massaging. Cells and debris were removed by centrifugation for $10 \mathrm{~min}$ at 500 or $1000 \times g$ $\left(4^{\circ} \mathrm{C}\right)$. The resulting supernatant was centrifuged at $20,000 \times g$ for $1 \mathrm{~h}\left(4^{\circ} \mathrm{C}\right)$. The pelleted surfactant complex was extracted overnight three to four times with stirring in chloroform $/ \mathrm{meth}$ anol $(2: 1$, vol/vol; $3 \mathrm{mg}$ phospholipid/ml). Insoluble material was removed by centrifugation at $10,000 \times g$ for $30 \mathrm{~min}\left(4^{\circ} \mathrm{C}\right)$. 
The supernatant from the final extraction was concentrated by partial evaporation of the solvent under nitrogen, then applied to either an analytic column $(1 \times 50 \mathrm{~cm})$ or to a preparative column $(2.5 \times 100 \mathrm{~cm})$ of Sephadex LH-20 that had been equilibrated in chloroform/methanol $(2: 1, \mathrm{vol} / \mathrm{vol})$. Loads of approximately $35 \mathrm{mg} / 0.5 \mathrm{ml}$ or $400 \mathrm{mg} / 4 \mathrm{ml}$ were applied to the columns, respectively. Elution with the same solvent was carried out at a flow rate of $0.34 \mathrm{ml} / \mathrm{min}\left(20^{\circ} \mathrm{C}\right)$. The effluent was monitored at $280 \mathrm{~nm}$. Two-min fractions were collected and analyzed for protein by the methods of Lowry as modified by Peterson (26) or by amino acid analysis and by one-dimensional, SDS-PAGE (27). The fractions containing protein from each chromatograph were collected and pooled with similar fractions from successive runs. The other lipid-rich fractions containing protein were also collected and rerun on the column.

Characterization of proteins. PAGE with SDS was carried out as previously described $(15,27,28)$ using $15 \%$ acrylamide and $1.5 \mathrm{~mm}$-thick slab gels with $3.5 \%$ acrylamide stacking gels. The gels were stained with silver stain kits from N.E. Nuclear (Boston, MA). Molecular weight markers included myoglobins: III (2.5 $\mathrm{kDa})$, II (6.2 kDa), I (8.2 kDa), I and II (14.4 kDa) from LKB Laboratories (Paramus, NJ) and lactoalbumin (14.2 kDa), trypsin inhibitor $(20.0 \mathrm{kDa})$, trypsinogen $(24.0 \mathrm{kDa})$, carbonic anhydrase $(29.0 \mathrm{kDa})$, and glyceraldehyde-3 phosphate dehydrogenase $(36.0 \mathrm{kDa})$, albumin $(\mathrm{egg})(45.0 \mathrm{kDa})$, and albumin (bovine) $(66.0 \mathrm{kDa})$ from Sigma Chemical Co. (St. Louis, MO). Electrophoretic transfer and immunostaining of the proteins was done according to the methods of Burnette (29) as modified by Phelps et al. (28) using an immunoblotting apparatus (Bio-Rad, Richmond, CA) and nitrocellulose paper (Schleicher Schuell, Keene, NH) with a pore size of $0.05 \mu \mathrm{m}$. We used polyclonal rabbit antisera raised against surfactant TA proteins as previously described (34) to identify SP-B,C. We also used polyclonal rabbit antisera to the hydrophilic surfactant protein, SP-A, partially purified from pulmonary lavage of human patients with alveolar proteinosis $(28,30)$.

Amino acid composition was determined from protein-rich LH-20 fractions that were hydrolyzed in $6 \mathrm{~N} \mathrm{HCl}$ at $110^{\circ} \mathrm{C}$ for $24 \mathrm{~h}$. Free amino acid composition was determined with a Beckman 6300 Amino Acid analyzer. The quantity of protein used in recombinant studies was determined either by amino acid analysis or by Lowry assay with values normalized to amino acid equivalents.

Lipid analysis. Measurements of phosphorus in crude surfactant, organic solvent soluble extracts, and Sephadex LH-20 eluates were carried out after Folch extraction (31) and quantified by the methods of Weinhold and Villee (32). Samples of LH-20 eluates for lipid analysis were dried under nitrogen and redissolved in small volumes of chloroform/methanol $(2: 1, \mathrm{vol} / \mathrm{vol})$. The lipid components were separated by thin-layer chromatography on silica gel by using chloroform/methanol/2-propanol/ water/triethylamine (30:9:25:7:25, by volume) (33). After chromatography, solvents were removed by brief air drying followed by evaporation in an evacuated chamber for approximately $2 \mathrm{~h}$. The plates were then sprayed with $70 \%$ sulfuric acid and charred overnight at $180^{\circ} \mathrm{C}$.

Analysis of surface activity. The protein rich fractions in chloroform/methanol (2:1, vol/vol) from column chromatography were mixed with synthetic DPPC $(99+\%$ purity, Sigma $)$ in chloroform/methanol $(2: 1, \mathrm{vol} / \mathrm{vol})$ to achieve ratios ranging between 100:1 and 5:1 (wt/wt) of DPPC to protein. All suspensions except surfactant TA were briefly vortexed, dried under nitrogen, dispersed in distilled water with brief vortexing, frozen $\left(-70^{\circ} \mathrm{C}\right)$, lyophilized, and stored at $-20^{\circ} \mathrm{C}$ until use. Surfactant TA was the generous gift of Tokyo Tanabe Co. Its composition has been described by us and others (34-36). It was stored as a lyophilized powder at $-70^{\circ} \mathrm{C}$ until use. All mixtures were dispersed in $0.15 \mathrm{M}$ saline with sonication at $20 \%$ output (Branson Sonifier, model 185 with microtip) for three, 3-s bursts to a final concentration of $2.0 \mathrm{mg} / \mathrm{ml}$. The dispersions were tested in a pulsating bubble surfactometer (37). This instrument measures inflation pressures for a bubble in communication with ambient air in a surfactant suspension at $37^{\circ} \mathrm{C}$. The bubble is made to pulsate at 20 cycles/min between minimum and maximum radii of 0.40 and $0.55 \mathrm{~mm}$. We monitored inflation pressures for a 5 minute period after bubble creation.

In vivo testing. We adopted, with modification, the methods of Lachman et al. (38) and Taeusch et al. (34) for exogenous surfactant treatment of rats made surfactant deficient by multiple lavage. Adult, male Sprague-Dawley white rats weighing 0.355 $\pm 0.062 \mathrm{~kg}$ were anesthetized with an intraperitoneal injection of pentobarbital $(35 \mathrm{mg} / \mathrm{kg})$ followed 20 min later by a subcutaneous injection of ketamine $(80 \mathrm{mg} / \mathrm{kg})$. A 14-gauge catheter was inserted into the trachea and tied (Fig. 1). The left common carotid artery was then ligated, and a 22-gauge catheter was inserted proximal to the ligation into the artery for use in blood gas sampling, pressure monitoring, and fluid and drug administration. The animal was paralyzed with pancuronium bromide $(0.1 \mathrm{mg} / \mathrm{kg})$ given intraarterially. Anesthesia was maintained with hourly injection of ketamine $(12 \mathrm{mg} / \mathrm{kg})$ and injections of pancuronium $(0.08 \mathrm{mg} / \mathrm{kg})$ every $30 \mathrm{~min}$ and when paralysis declined. Body temperature was maintained using a heating pad (Delta Phase, Braintree Scientific, Braintree, MA) placed under the animal and with an overhead heat lamp. Physiologic saline with heparin (1000:1) was infused into the arterial catheter at $1.0 \mathrm{ml} / \mathrm{h}$. Blood removed for analysis was returned and saline was injected periodically to replace blood volume that was lost.

Ventilation was maintained with oxygen $(100 \%)$ at flow rates of $0.75 \mathrm{1} / \mathrm{min}(6.2 \mathrm{ml}$ stroke volume) using a time-cycled ventilator (34) or by means of a volume-controlled ventilator (Harvard Apparatus Co., South Natick, MA, model 683) using stroke volumes of $7.2 \mathrm{ml} / \mathrm{kg}$. Ventilator rates were adjusted to maintain the $\mathrm{paCO}_{2}$ between 25 and 55 torr, our goal being $40-45$ torr.

Arterial blood gases were obtained immediately before paral-

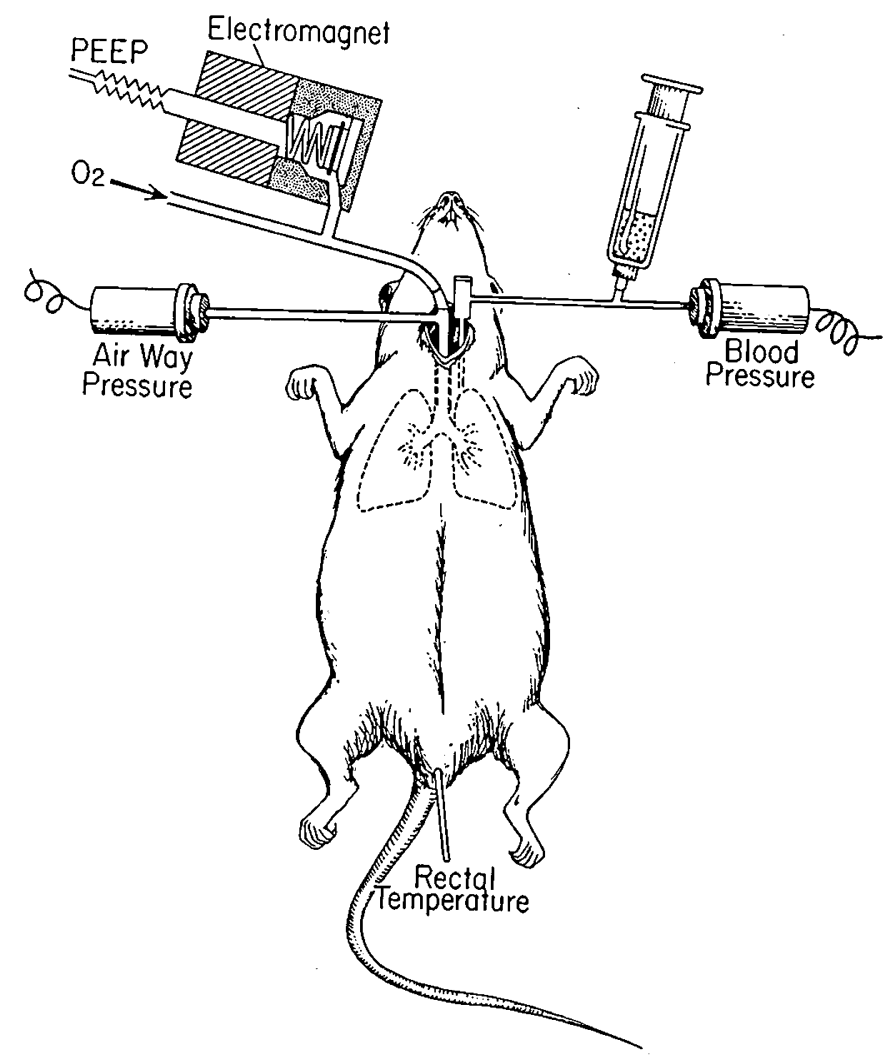

Fig. 1. Schematic of the experimental set-up used for in vivo testing of surfactant. 
ysis and artificial ventilation, 5 min after ventilation, and at 10min intervals until blood gas concentrations were stable. Thirty min later the animals were given several sigh breaths $\left(2 \times V_{t}\right)$ and lavaged four times by $20 \mathrm{ml} / \mathrm{kg}$ instillation and aspirations of saline $\left(37^{\circ} \mathrm{C}\right)$. Additional lavages were performed if arterial $\mathrm{paO}_{2}$ remained more than 120 torr after the first four lavages. Sigh breaths were given before each lavage and after the last lavage. After the last lavage, positive end expiratory pressure of $4 \mathrm{~cm} \mathrm{H}_{2} \mathrm{O}$ was applied and maintained for the duration of the experiment. The animals received instillations of either air (sham treatment), DPPC, surfactant TA, or DPPC/protein (9:1) after 30 min of stable blood gases.

The surfactants were prepared at a concentration of either 30 or $15 \mathrm{mg} / \mathrm{ml} 0.15 \mathrm{M}$ saline and dispersed by brief sonication. Dilution to $15 \mathrm{mg} / \mathrm{ml}$ saline was done to reduce the viscosity of the DPPC and DPPC/protein mixtures $(9,39)$. Surfactant TA, DPPC/protein, and DPPC-treated animals received dosages of $50 \mathrm{mg} / \mathrm{kg}$. These instillations were carried out over a $5-\mathrm{min}$ period in quarter doses with rats positioned supine, prone, and on either side to distribute the instillate. Sigh breaths were given after each quarter dose. Blood gases were obtained 5 min after surfactant administration and at 30-min intervals for up to 21 / $2 \mathrm{~h}$.

At the termination of the experiment (approximately $2 \mathrm{~h}$ after instillation) the trachea was clamped and the lungs degassed (40). Immediately after death, lung-thorax closed chest compliance was measured at one-half full inflation $(8 \mathrm{ml})(41)$ and normalized to body weight.

Statistical analyses. Evaluation of statistical significance between groups was carried out by one-way analysis of variance with $p<0.01$ accepted as significant.

\section{RESULTS}

Protein isolation. The chloroform/methanol soluble, bovine lung surfactant lipid extract contained approximately $1 \%$ protein (by Lowry assay) relative to phospholipids by weight. Figure 2 illustrates the elution patterns of the proteins and phospholipids present in the lipid extracts after Sephadex LH-20 liquid chromatography. The proteins appeared slightly earlier than the main lipid peak that contained primarily phosphatidylcholine (fractions 11-15), sphingomyelin (fractions 11-15), and phosphatidylethanolamine (fractions 15-19) (Fig. 3). The more acidic phospholipids: phosphatidylserine (fraction number 30 ), phosphatidylinositol (fraction 57), and phosphatidylglycerol (fraction numbers 57 and 70) eluted later. In two pooled samples of protein-rich fractions, some lipid phosphorus was present giving an estimated phospholipid to protein weight (wt/wt) ratio of 2.4 (assuming phosphorus as $4 \%$ of phospholipid weight). Thin-layer chromatography of one of these samples showed that the principal lipid was phosphatidylcholine and there was some streaking of lipid through the remainder of the plate. Some charring occurred near the solvent front indicating the possibility that neutral lipids may have been present in the protein-rich fractions.

In the protein-rich fractions from Sephadex LH-20 chromatography, three major bands at 6,14 , and 18-26 kDa could be identified under nonreducing conditions by SDS-PAGE (Fig. 2). When 2-mercaptoethanol was added to samples before electrophoresis, we observed almost no $18-$ to $26-\mathrm{kDa}$ band and increased density in the 5- to 6-kDa and $14-\mathrm{kDa}$ bands. When smaller amounts of protein were used for SDS-PAGE, bands only at $18-26 \mathrm{kDa}$ could be seen under nonreducing conditions and at 5-6 kDa under reducing conditions. In other work, we

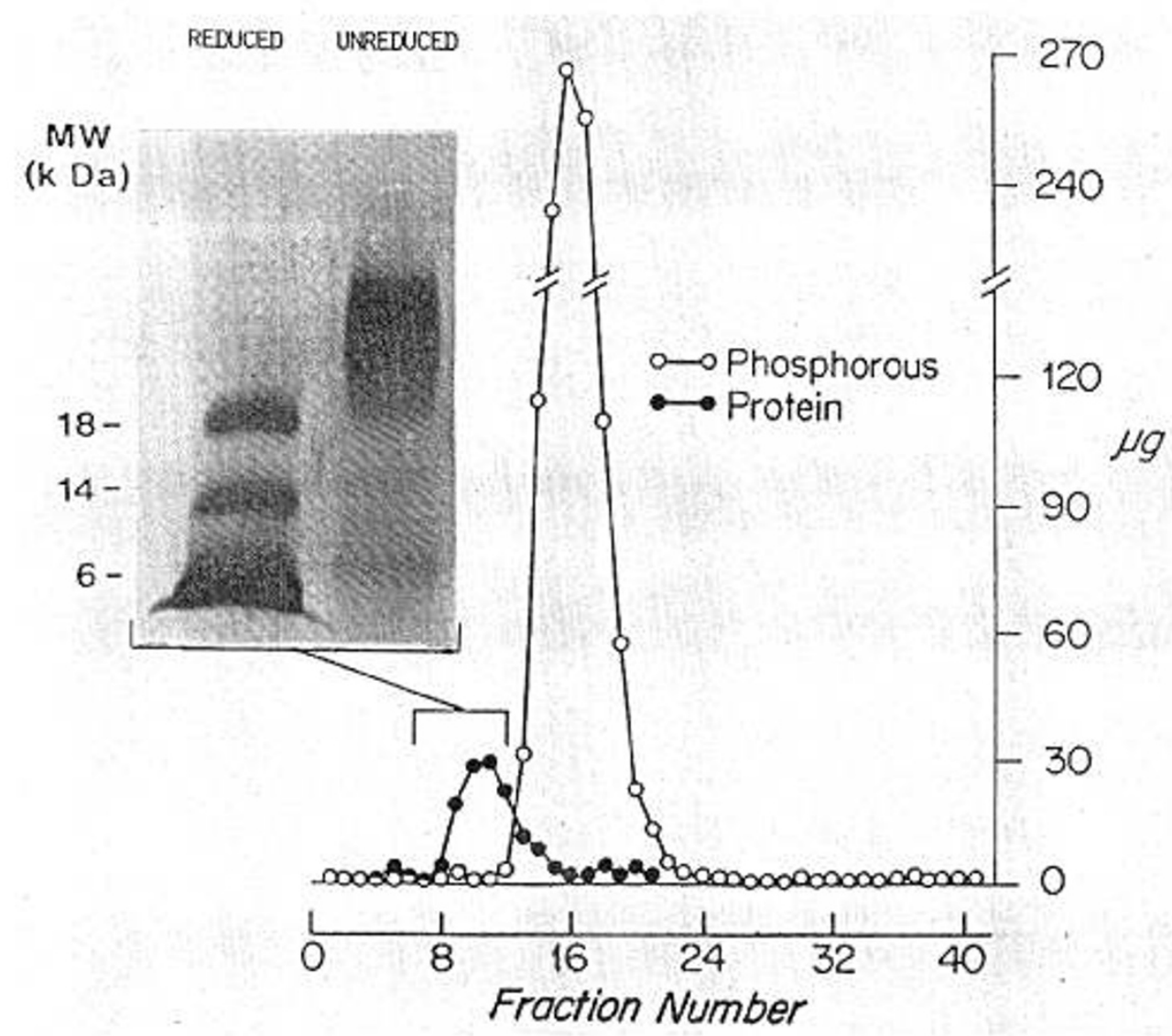

Fig. 2. Elution profile of the proteins and phospholipid in Sephadex LH-20 eluates of lipid extract of whole bovine lung surfactant. Chloroform/ methanol $(2: 1: \mathrm{vol} / \mathrm{vol})$ was used as solvent and mobile phase. Inset are electrophoretic patterns of the eluting proteins with (lane 1) and without the presence of a reducing agent (lane 2). Surfactant proteolipids appear in fractions 8-15 and the major surfactant lipids appear in fractions 11-23. The ordinate indicates $\mu \mathrm{g}$ of either phosphorous or protein. 


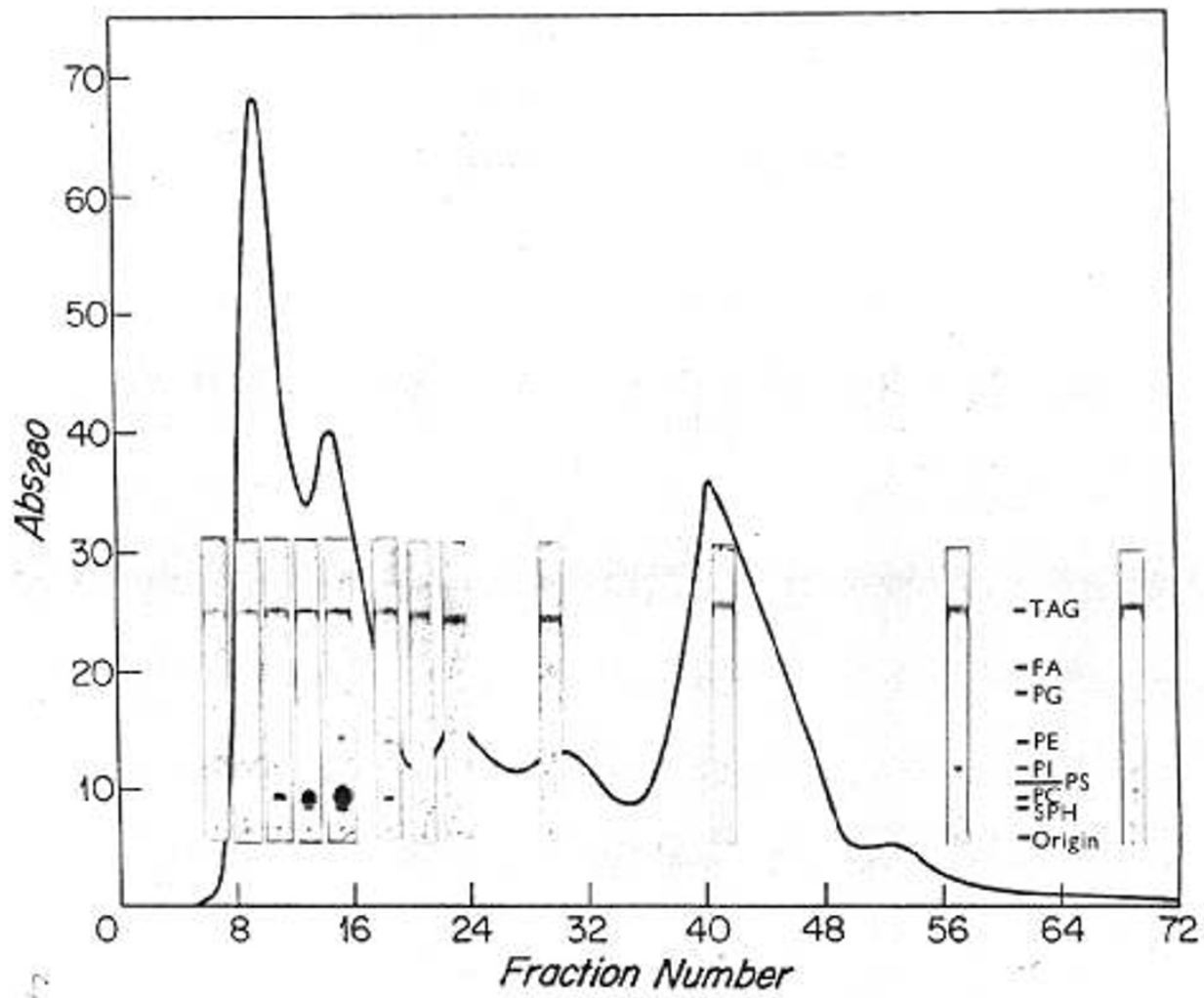

Fig. 3. Absorbance profile for lipid extracts of whole lung surfactant after chromatography using Sephadex LH-20. Fraction numbers are the same as in Figure 2. Superimposed according to fraction number are results from thin-layer chromatography of selected fractions. The migration patterns for the various lipids are given at right. The ordinate indicates absorbance at $280 \mathrm{nM}$. SPH, sphingomeylin; PC, phosphatidylcholine; PS, phosphatidylserine; PI, phosphatidylinositol; PE, phosphatidylethanolamine; PG, phosphatidylglycerol; FA, free fatty acids; TAG, triacylglycerols. The lipid most closely associated with the hydrophobic surfactant proteins consistently appears to be phosphatidylcholine.

have determined that the unreduced band at $18-26 \mathrm{kDa}$ contains SP-B and SP-C, and the unreduced bands at 5 and $14 \mathrm{kDa}$ are SP-C (16). These proteins were immunoreactive with antibodies to surfactant TA. SP-A was not detected in liquid chromatography fractions by SDS-PAGE with silver staining or immunoblot analysis.

Pulsating bubble surfactometer. Suspensions of DPPC alone showed poor adsorption to the air-liquid interface (Fig. 4) and were ineffective at reducing the inflating pressures of the bubbles in the pulsating bubble surfactometer up to $5 \mathrm{~min}$ after bubble creation (Fig. 5, Table 1). The addition of $10 \%$ by weight of SP$\mathrm{B}, \mathrm{C}$ to DPPC resulted in increased adsorption rates (Fig. 4) and lower surface tension (Fig. 5) that were similar to those exhibited by surfactant TA (Fig. 4; Table 1). No additional reduction in surface tensions were seen when SP-B,C were increased to $20 \%$ by weight of DPPC. Based on these results, we used DPPC/SPB,C (9:1) for testing in surfactant-deficient adult rats.

In vivo comparisons. Sham- and DPPC-treated animals generally showed no improvement in arterial oxygenation after treatment (Fig. 6). Animals receiving either surfactant TA or DPPC/SP-B,C (9:1) mixtures showed improvements in arterial oxygenation at $5 \mathrm{~min}$ after treatment that were generally sustained for the experimental period. DPPC/SP-B,C and surfactant TA-treated rats generally maintained stable, normal blood $\mathrm{paCO}_{2}$, and $\mathrm{pH}$ levels after treatment and had lungs that appeared well aerated on postmortem inspection. Static lung compliance measures for surfactant TA- $\left(1.9 \pm 0.2 \mathrm{ml} / \mathrm{cm} \mathrm{H} \mathrm{H}_{2} \mathrm{O} / \mathrm{kg}, n=8\right)$ and DPPC/SP-B,C-treated rats $\left(2.3 \pm 0.4 \mathrm{ml} / \mathrm{cm} \mathrm{H}_{2} \mathrm{O} / \mathrm{kg}, n=\right.$ 5) were not significantly different from each other but were significantly greater than those of sham- (air) $(1.3 \pm 0.1 \mathrm{ml} / \mathrm{cm}$ $\left.\mathrm{H}_{2} \mathrm{O} / \mathrm{kg}\right)$ and DPPC-treated rats $(1.2 \pm 0.1)(p<0.01)$.

\section{DISCUSSION}

We have tested the in vitro and in vivo efficacy of mixtures of DPPC and the small, hydrophobic proteins (SP-B,C) unique to pulmonary surfactant. Simple mixtures similar to those studied herein have been variously studied by a number of other investigators (Table 2) and have been shown to have many biophysical properties similar to natural surfactants. Because of different techniques for isolation and measurement of these proteins, the reported number and molecular weights of these proteins have varied. However, recently two small hydrophobic surfactant proteins with molecular weights of approximately $5 \mathrm{kDa}$ under reducing conditions have been cloned $(18,21,23)$ and their amino acid sequences reported $(18,20-23,25)$. These two proteins have $\mathrm{N}$-terminal amino acids of phenylalanine and leucine/ isoleucine when isolated from bovine lung, and evidence suggests that amino acid sequences are similar when these are proteins isolated from different species. Our test mixtures contained both SP-B (Phe) and SP-C (Leu/lle) (16). We and others suspect that the native low molecular weight surfactant proteins are heterooligomers of these two gene products $(12,16)$. For this reason (and because we were unable to isolate SP-B and SP-C separately in sufficient amounts for the in vivo studies), we used both SP-B and SP-C together in these studies of function. Our observation that the presence of SP-B,C enhances in vitro surface activity of DPPC is in qualitative agreement with others who have studied similar mixtures $(5,6,9)$. Our study is unique in that serial measures of gas exchange and measurement of static lung compliance were carried out in surfactant-deficient animals after treatment with DPPC/SP-B,C. Our study differs from some other studies in that we chose to use SP-B,C mixed with DPPC alone, without addition of other surfactant lipids. By so doing, it is possible that we needed a higher protein:DPPC ratio than others have found necessary when other protein and/or lipid surfactant constituents are included $(2,10)$.

Whereas others $(2,4,6,7,9)$ have tested mixtures similar to ours in premature rabbit fetuses, the rabbit model does not readily allow measurements of both gas exchange and lung mechanics over time. Nonetheless, the surfactant-deficient adult 


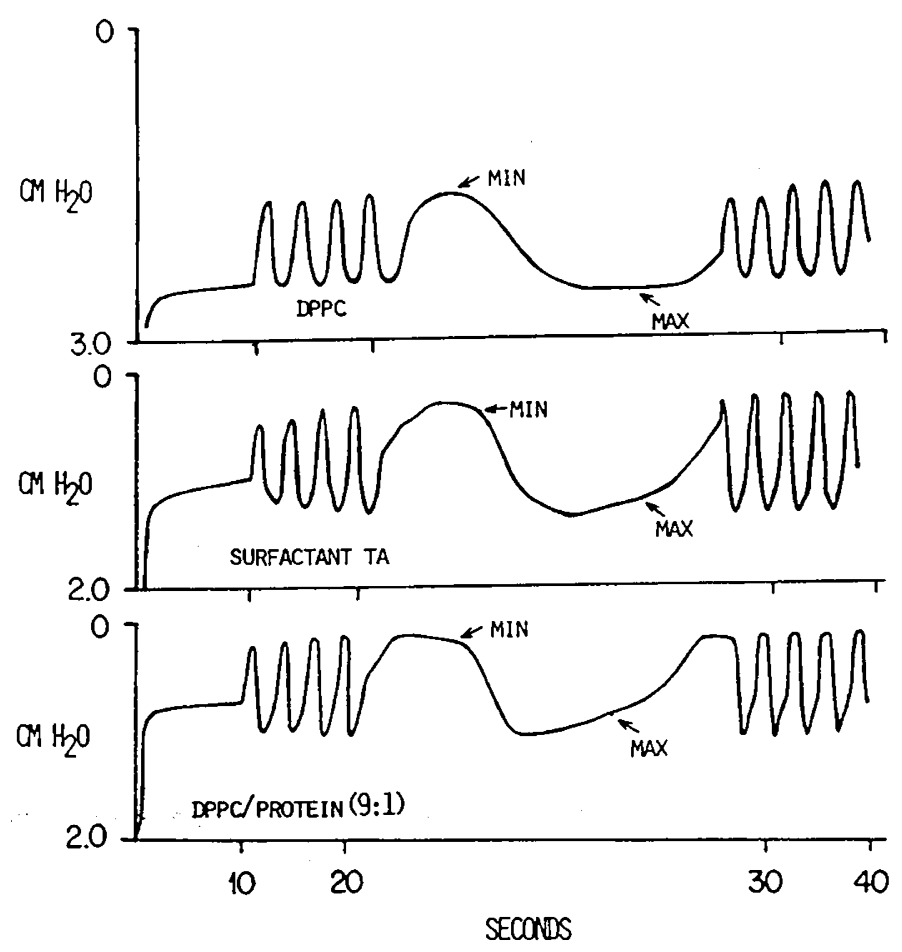

Fig. 4. Representative recordings of inflation pressures of bubbles in solutions of DPPC, surfactant TA, and DPPC/SP-B,C (9:1) assayed by a pulsating bubble surfactometer. The bubble is created at time zero with pulsation at $20 \mathrm{cycles} / \mathrm{min}$ between radii of $0.55 \mathrm{~mm}(\max )$ and 0.40 $\mathrm{mm}(\mathrm{min})$ begun after $10 \mathrm{~s}$. All mixtures were at concentrations of 2.0 $\mathrm{mg} / \mathrm{ml}\left(37^{\circ} \mathrm{C}\right)$.

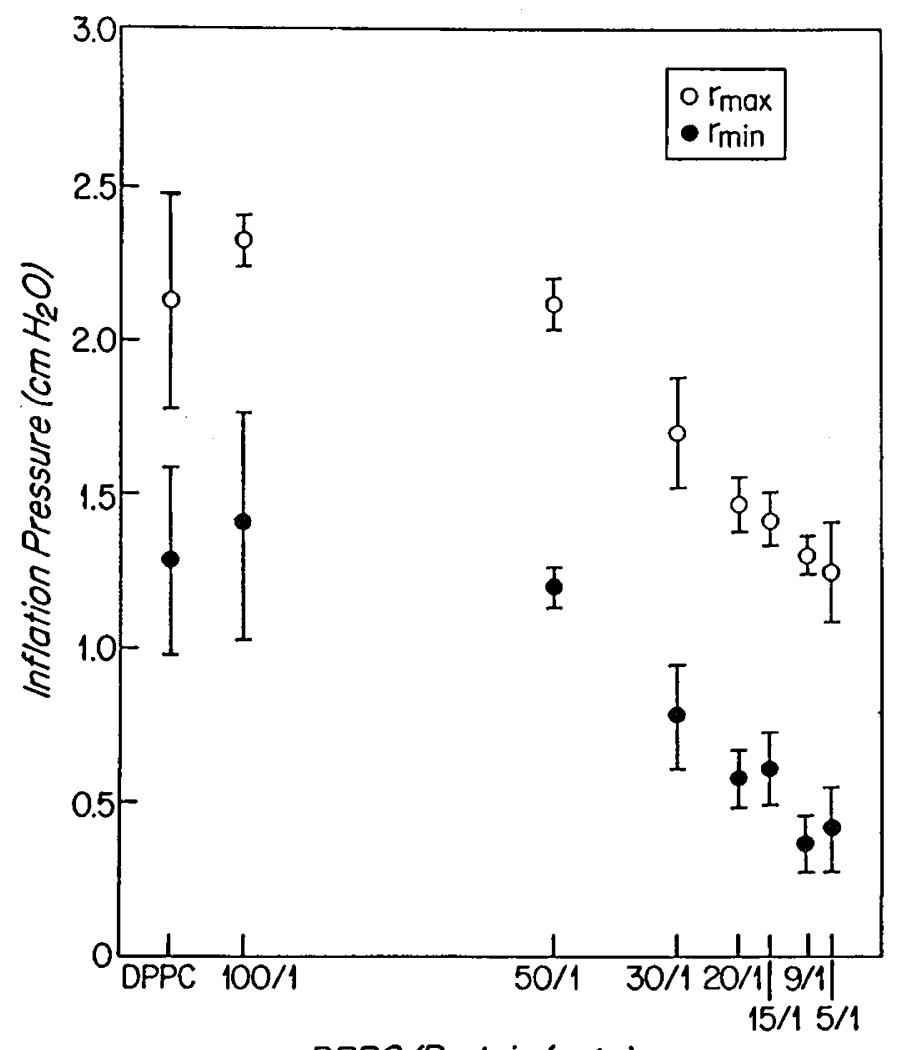

DPPC/Protein $(w / w)$

Fig. 5. Inflation pressures of DPPC or mixtures of DPPC and SP-B,C were measured on a pulsating bubble surfactometer. Means \pm SEM are given for bubbles at maximum $(0.55 \mathrm{~mm})$ and minimum radius $(0.40$ $\mathrm{mm}$ ) after 20 inflation cycles $(1.0 \mathrm{~min}) . n=13$ for DPPC alone and $n=$ 3 for all others.
Table 1. Surface tension $(\mathrm{mN} / \mathrm{m}) *$ of DPPC, surfactant $T A$, and $D P P C / S P L 5-26$ solutions

\begin{tabular}{lrlccc}
\hline & $n$ & \multicolumn{1}{c}{$15 \mathrm{~s}$} & $1 \mathrm{~min}$ & $3 \mathrm{~min}$ & $5 \mathrm{~min}$ \\
\hline DPPC & 13 & $29 \pm 2 \dagger$ & $26 \pm 2 \dagger$ & $22 \pm 1 \dagger$ & $21 \pm 2 \dagger$ \\
Surfactant TA & 7 & $10 \pm 1$ & $6 \pm 1$ & $5 \pm 0.5$ & $5 \pm 0.5$ \\
DPPC/SPL5-26 & 24 & $13 \pm 1 \mathrm{NS}$ & $7 \pm 1 \mathrm{NS}$ & $4 \pm 1 \mathrm{NS}$ & $3 \pm 1 \mathrm{NS}$ \\
$(9: 1)$ & & & & & \\
\hline
\end{tabular}

$*$ Means \pm SEM for three to six measurements/sample at a minimum bubble radius of $0.4 \mathrm{~mm}$ using a pulsating bubble surfactometer. Times indicate the period of bubble pulsation.

$\dagger$ In comparison to surfactant TA, $p<0.01$.

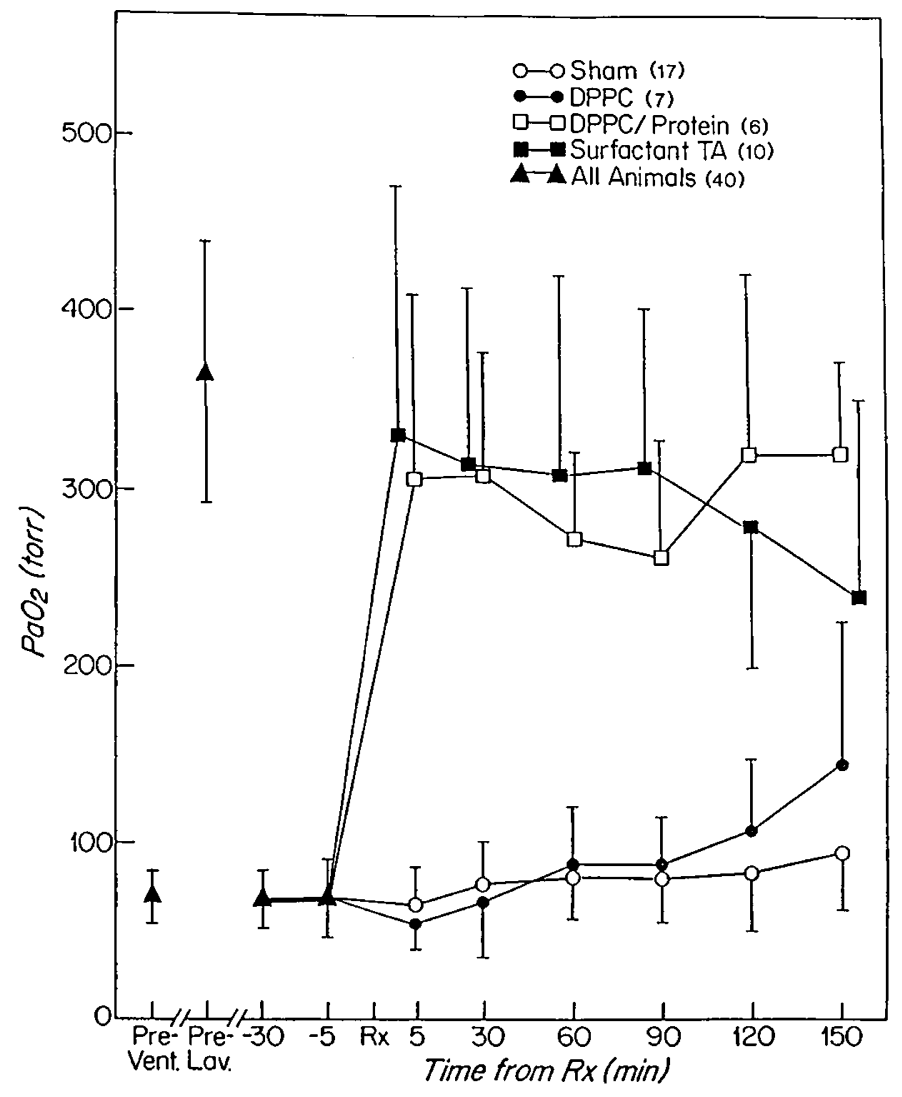

Fig. 6. Serial measurements of arterial oxygen levels in surfactantdeficient adult rats before ventilation (pre-vent.), before lavage (pre-lav.), and pre- and posttreatment are illustrated. The dosage for all treated animals was $50 \mathrm{mg} / \mathrm{kg}$ at concentrations of either 30 or $15 \mathrm{mg} / \mathrm{ml}$ saline. Sample sizes given are for each group up to $90 \mathrm{~min}$ posttreatment with $n=33$ at prelavage and $n=39$ at 5 min pretreatment due to sampling errors. Deaths occured as follows: sham (1), DPPC (1), and surfactant TA (2) at 120 min posttreatment; sham (1), and DPPC (1) at $150 \mathrm{~min}$ posttreatment. Mean \pm SEM given at prelavage as three to four measurements per rat (each separated by at least $10 \mathrm{~min}$ ) were averaged; means \pm SD are given for all other points. Values for DPPC/protein SPL5-26-treated rats are significantly different from sham- and DPPCtreated animals for all time points posttreatment and are not significantly different from surfactant TA-treated animals at any time point. Values for surfactant TA are significantly different at all time points from shamtreated animals and at all time points except 150 min posttreatment from DPPC-treated animals.

rat model has limitations as well, 1) an absence of lung immaturity, 2) possible damage to lung epithelium caused by the lavage procedure, and 3) potential effects of residual lavage fluid on the response by the lung to test mixtures. Using immature sheep $(42,43)$ or primates $(44)$ may be ideal models in which to test these mixtures, but limitations include the need for larger amounts of test material and expense. 
Table 2. Efficacy of low m.w. surfactant proteins when mixed with surfactant phospholipid(s)*

\begin{tabular}{|c|c|c|c|c|c|}
\hline \multirow[b]{2}{*}{ Reference } & \multirow[b]{2}{*}{ Source } & \multirow[b]{2}{*}{ Lipids } & \multirow{2}{*}{$\begin{array}{l}\text { Proteins } \\
\text { (m.w., red) }\end{array}$} & \multicolumn{2}{|c|}{ Measurements } \\
\hline & & & & In vitro & In vivo \\
\hline $\begin{array}{l}\text { Hawgood et al. } \\
\quad(1,2)\end{array}$ & Dog & $\mathrm{DPPC} / \mathrm{PG}$ & $5,8 \mathrm{kDa}$ & $\mathrm{K} / \mathrm{C}$ & $\mathrm{PIP}, \mathrm{C} / \mathrm{L}$ \\
\hline $\begin{array}{l}\text { Yu and Poss- } \\
\text { mayer (11) }\end{array}$ & Calf & DPPC/PG & 6 & $\mathrm{P} / \mathrm{S}$ & \\
\hline Revak et al. (4) & Human & $\mathrm{DPPC} / \mathrm{PG}$ & 6 & $\mathrm{P} / \mathrm{S}$ & \\
\hline Suzuki et al. (9) & Pig & $\mathrm{DPPC} / \mathrm{PG}$ & $<15$ & $\begin{array}{l}\mathrm{P} / \mathrm{S} \\
\mathrm{W} / \mathrm{B}\end{array}$ & $\begin{array}{l}\mathrm{P} / \mathrm{V} \\
\text { hist. }\end{array}$ \\
\hline $\begin{array}{c}\text { Takahashi and } \\
\text { Fujiwara (5) }\end{array}$ & Cow & DPPC & 5 & $\mathrm{P} / \mathrm{S}$ & \\
\hline $\begin{array}{l}\text { Tanaka et al. } \\
(6,7)\end{array}$ & Cow & DPPC & 10 & $\begin{array}{l}K / C \\
W / B\end{array}$ & $\mathrm{P} / \mathrm{V}$ \\
\hline $\begin{array}{l}\text { Notter et al. } \\
\text { (10) }\end{array}$ & Cow & $\mathrm{DPPC} / \mathrm{PG}+$ & 6 & $\mathrm{P} / \mathrm{S}$ & \\
\hline Current & Cow & DPPC & $\begin{array}{l}5-26 \\
(S P-B, C)\end{array}$ & $\mathrm{P} / \mathrm{S}$ & $\begin{array}{l}G / E \\
C / L\end{array}$ \\
\hline
\end{tabular}

* PIP, peak inspiratory pressure; $\mathrm{PG}$, phosphatidyl glycerol; $\mathrm{C} / \mathrm{L}$, compliance of lung; $P / S$, pulsating surfactometer; $K / C$, King/Clements' measure of adsorption rate; W/B, Wilhelmy balance measure of surface tension; $P / V$, pressure/volume measures of lung; $G / E$, gas exchange; hist, histology; MW red, m.w. after reduction of sulfhydryl bonds. All in vivo studies with the exception of the current one were carried out in premature rabbits.

We have considered the possibility that our results with DPPC/ SP-B,C are due in part to the presence of lipid that coisolate with these proteins. It is not yet known whether part of the hydrophobicity of these proteins is due to covalent binding of lipid, i.e. whether these proteins are proteolipids. The only lipid that we could identify that coisolated with SP-B,C was phosphatidylcholine, and that was found in varying amounts in different batches. Based on these findings and the work of others, we think it unlikely that lipid bound to SP-B,C, rather than SP-B,C per se, is responsible for alteration of the biophysical behavior of the DPPC/SP-B,C dispersions.

In summary, our results clearly indicate that a simple aqueous dispersion of hydrophobic low molecular weight surfactant proteins and DPPC have in vitro and in vivo characteristics that are similar to a more extensively tested "natural" surfactant. Further testing of simpler surfactant mixtures may allow insights into mechanisms of action and metabolism of alveolar surfactant, and may offer new approaches for improved treatment of surfactant deficiency states.

\section{REFERENCES}

1. Hawgood S, Benson BJ, Schilling J, Damm D, Clements JA, White RT 1987 Nucleotide and amino acid sequences of pulmonary surfactant protein SP 18 and evidence for cooperation between SP 18 and SP 28-36 in surfactant lipid adsorption. Proc Natl Acad Sci USA 84:66-70

2. Hawgood S, Schlueter MA, Brown CL, Tooley WH, Buckley D, White RT, Benson BJ 1987 Effects of phospholipids (PL), recombinant human surfactant glycoprotein (SP28-36) and human surfactant proteins (SP5, SP18) on the pulmonary mechanics of premature rabbits. Pediatr Res $21: 4: 45 \mathrm{~A}(\mathrm{abstr})$

3. Possmayer F, Yu S-H, Chung W, Olafson RW, Harding PGR 1987 Functional studies on the $6 \mathrm{kDa}$ apoprotein group associated with pulmonary surfactant. Soc Gynecol Invest 34:60(abstr)

4. Revak SD, Merritt TA, Hallman M, Cochrane CG 1987 A low molecular weight (LMW) apoprotein (5-12 kD) and phospholipid reconstitutive human lung surfactant activity. Pediatr Res 21:4:464A(abstr)

5. Takahashi A, Fujiwara T 1986 Proteolipid in bovine lung surfactant: its role in surfactant function. Biochem Biophys Res Commun 135:527-532

6. Tanaka T, Takei T, Aiba T, Kazus A, Akira K, Fujiwara T 1986 Development of synthetic lung surfactants. J Lipid Res 27:475-485

7. Tanaka Y, Takei T, Kanazawa Y 1983 Lung Surfactants. II. Effects of fatty acids, triacylglycerols and protein on the activity of lung surfactant. Chem Pharm Bull 31:4100-4109

8. Whitsett JA, Ohning BL, Ross G, Meuth J, Weaver T, Holm BA, Shapiro DL, Notter RH 1986 Hydrophobic surfactant-associated protein in whole lung surfactant and its importance for biophysical activity in lung surfactant extracts used for replacement therapy. Pediatr Res 20:460-467

9. Suzuki Y, Curstedt T, Grossman G, Kobayashi T, Nilsson R, Nohara K, Robertson B 1986 Experimental studies on the role of the low-molecular weight ( $\leq 15,000$-daltons) apoproteins of pulmonary surfactant. Eur J Respir Dis 69:336-345

10. Notter R, Shapiro D, Ohning B, Whitsett J 1987 Biophysical activity of synthetic phospholipids combined with purified lung surfactant 6000 dalton apoprotein. Chem Phys Lipids 44:1-17

11. Yu S, Possmayer F 1986 Reconstitution of surface activity by using the $6 \mathrm{kDa}$ apoprotein associated with pulmonary surfactant. J Biochem 236:85-89

12. Possmayer F, Yu S-H, Chung W, Olafsson RW Characterization of the $6 \mathrm{kDa}$ apoprotein associated with pulmonary surfactant. BBRC (in press)

13. Claypool WD, Chander A, Fisher AB 1981 Isolation of the hydrophobic apoproteins of rat lung surfactant. Fed Proc 40:408(abstr)

14. Claypool WD, Wang DL, Chander A, Fisher AB 1984 "Hydrophobic" surfactant apoproteins and augmentation of phospholipid recycling. Exp Lung Res 6:215-222

15. Phelps DS, Smith LS, Taeusch HW 1987 Characterization and partial amino acid sequence of a low molecular weight surfactant protein. Am Rev Respir Dis 135:1112-1117

16. Takahashi A, Smith GB, Taeusch HW 1988 Separation of two pulmonary surfactant proteolipids in lung surfactant using high performance liquid chromatography. J Clin Res 36:245A

17. Wang DL, Rotman EI, Chander A, Fisher AB 1984 Characterization of hydrophobic surfactant apoproteins. Fed Proc 43:1643(abstr)

18. Whitsett JA, Glasser SW, Korfhagen TR, Weaver TE, Clark J, Pilot-Matias T, Meuth J, Fox JL 1987 Deduced amino acid sequence of human pulmonary surfactant proteolipid: SPL(p val). Fed Proc 46:2097(abstr)

19. Claypool WD, Wang WL, Chander A, Fisher AB 1984 An Ethanol/ether soluble apoprotein from rat lung surfactant augments liposome uptake by isolated granular pneumocytes. J Clin Invest 74:677-684

20. Whitsett JA, Hull WM, Ohning B, Ross G, Weaver TE 1986 Immunologic identification of a pulmonary surfactant-associated protein of molecular weight $=6,000$ daltons. Pediatr Res 20:744-749

21. Warr R, Hawgood S, White RT, Damm D, Schilling J, Benson B 1987 Gene and cDNA sequence of pulmonary surfactant protein SP5. Am Rev Respir Dis 135:a378(abstr)

22. White RT, Hawgood S, Damm D, Spratt K, Schilling J, Benson B 1987 Sequence for pulmonary surfactant protein SP18 and evidence for cooperation between SP18 and SP28-36 in surfactant lipid adsorption. Am Rev Respir Dis 135:A379(abstr)

23. Jacobs K, Phelps DS, Steinbrink R, Fisch J, Kriz R, Mitsock L, Daugherty $\mathbf{J}$ Taeusch HW, Floros J 1987 Isolation of a cDNA clone encoding a high molecular weight precursor to a $6-\mathrm{kDa}$ pulmonary surfactant-associated protein. J Biol Chem 262:9808-9811

24. Weaver TE, Kropp DL, Whitsett JA 1987 Processing of pulmonary surfactant proteolipid SPL (phe) in rat lung type II epithelial cells. Fed Proc 46:1980(abstr)

25. Glasser SW, Korfhagen TR, Weaver T, Pilot-Matias T, Fox JL, Whitsett JA $1987 \mathrm{cDNA}$ and deduced amino acid sequence of human pulmonary surfactant-associated proteolipid SAP (phe). Proc Natl Acad Sci USA 84:40074011

26. Peterson GL 1977 A simplification of the protein assay method of Lowry et al. which is more generally applicable. Anal Biochem 83:346-356

27. Laemelli UK 1970 Cleavage of structural proteins during the assembly of the head of bacteriophage T4. Nature 277:680-685

28. Phelps DS, Taeusch HW, Benson B, Hawgood S 1984 An electrophoretic and immunochemical characterization of human surfactant-associated proteins. Biochem Biophys Acta 791-266-238

29. Burnette WN 1981 "Western blotting": electrophoretic transfer of proteins from sodium dodecyl sulfate-polyacrylamide gels to unmodified nitrocellulose and radiographic detection with antibody and radioiodinated protein. Anal Biochem 112:195-203

30. Whitsett JA, Hull W, Ross G, Weaver TE 1985 Characteristics of human surfactant-associated glycoproteins. Pediatr Res 19:501-509

31. Folch J, Lees M, Sloane-Stanley GH 1956 A simple method for the isolation and purification of total lipids from animal tissues. J Biol Chem 497-509

32. Weinhold PA, Villee CA 1965 Phospholipid metabolism in the liver and lung of rats during development. Biochem Biophys Acta 106:540-550

33. Touchstone JC, Chen JC, Beaver KM 1980 Improved separation of phospholipids in thin layer chromatography. Lipids 15:61-62

34. Taeusch HW, Keough KMW, Williams M, Slavin R, Steele E, Lee AS, Phelps DS, Kariel V, Floros J, Avery ME 1986 Characterization of an exogenous bovine surfactant for infants with respiratory distress syndrome. Pediatrics 77:572-581

35. Fujiwara T, Tanaka Y, Takei $\mathrm{T} 1979$ Surfactant properties of artificial surfactant lipids. IRCS Med Sci 17:311

36. Fujiwara $T 1973$ Surfactant replacement in neonatal respiratory distress syndrome. In: Robertson B, Van Golde LMG, Battenberg JJ (eds) Pulmonary Surfactant. Elsevier, Amsterdam, The Netherlands, pp 479-503

37. Enhorning G 1977 Pulsating bubble technique for evaluating pulmonary surfactant. J Appl Physiol 43:198-203

38. Lachman B, Robertson B, Vogel J 1980 In vivo lung lavage as an experimental model of the respiratory distress syndrome. Anesth Scand 24:231-236

39. Metcalf IL, Burgoyne R, Enhorning G 1982 Surfactant supplementation in the preterm rabbit: effects of applied volume on compliance and survival. Pediatr

Res 16:834-839
40. Stengel PW, Frazer DG, Weber KL 1980 Lung degassing: an evaluation of two 
methods. J Appl Physiol 48:373-375

41. Kobayashi T, Kataoka H, Ueda T, Murakami S, Takada Y, Kokubo M 1984 Effects of surfactant supplement and end-expiratory pressure in lung-lavaged rabbits. J Appl Physiol 57:995-1001

42. Egan EA, Notter RH, Kwong MS, Shapiro DL 1983 Natural and artificial lung surfactant replacement therapy in premature lambs. J Appl Physiol 55:875883
43. Jobe A, Ikegami M, Jacobs H, Jones S 1984 Surfactant and pulmonary blood flow distributions following treatment of premature lambs with natural surfactant. J Clin Invest 73:848-856

44. Vidyasagar D, Maeta H, Raju TNK, John E, Bhat R, Go M, Dahiya U, Roberson Y, Yamin A, Narula A, Evans M 1985 Bovine surfactant (surfactant TA) therapy in immature baboons with hayaline membrane disease. Pediatrics 75:1132-1142 